\title{
Explanatory Factors for Public Transportation Financing Needs in Spain
}

\author{
María Luisa Delgado Jalon, Miguel Angel Sanchez de Lara, and Vera Gelashvili \\ Business Economics Department, King Juan Carlos University, Campus of Vicalvaro, Paseo de los Artilleros s/n., \\ 28032 Vicalvaro, Madrid, Spain \\ Correspondence should be addressed to Vera Gelashvili; vera.gelashvili@urjc.es
}

Received 5 February 2019; Revised 30 April 2019; Accepted 22 May 2019; Published 20 June 2019

Academic Editor: Jose E. Naranjo

Copyright (C) 2019 María Luisa Delgado Jalon et al. This is an open access article distributed under the Creative Commons Attribution License, which permits unrestricted use, distribution, and reproduction in any medium, provided the original work is properly cited.

\begin{abstract}
Public transport financing in Spain has generated interest due to the absence of a governing regulatory framework. There is a need for rules that help allocate public subsidies to guarantee the system's financial sustainability. Without explicit regulation, the current system for assigning and distributing public funding among Spanish cities has become unbalanced. Our goal is to identify the principal factors that explain why urban transport services in different cities require varying levels of public financing. Our results show that variables such as the "passengers," "number of vehicles," "number of employees," "autonomous community deficit", and "population density" are influencing factors for the needs of public subsidies.
\end{abstract}

\section{Introduction}

Public transport is an essential component of a country's development. Authorities are expected to provide citizens with an effective, accessible, secure, and equitable transportation service. If cities' economic activity is to develop sustainably, transport must be organized so that it facilitates the mobility of people and goods [1].

In the realm of public transport, the concept of sustainability has been amply studied from an environmental and social point of view [2]. Nevertheless, economic and financial analyses are less frequent. Those that exist focus mainly on intra- and/or intercountry analysis [3]. Many cities around the world face deficitary public transport systems with low productivity and high operational costs requiring government aid [4] that exceeds rational and financial sustainability criteria. The literature also delves into questions related to the ideal balance of private contributions (fees) and public aid (subsidies) with respect to service costs and how much each of those categories should increase over time.

Clearly, this is an international issue. Public transport is widely seen as a basic public service that authorities are required to offer [5]. Throughout the world, governments are committed to modern transportation systems that promote sustainable mobility and must finance at least some of their operational costs through subsidies. Notwithstanding, the proportion and form of public financing can vary among countries, regions, and even cities in the same country. Such is the case in Spain where these divergences are accentuated by the lack of state-level regulation guaranteeing equal distribution of transportation subsidies [6].

In consequence, in the present study we attempt to identify what variables impact public financing for Spanish urban transportation services. Such variables could form the basis of a coordinated plan to distribute subsidies. To this end, we consider the fare deficit-or portion of operational costs not covered through revenue and thus the amount needing to be subsidized - as the dependent variable. Our results are a useful illustration of the need for regulating the allocation of financing in a way that creates fair division of public aid. We demonstrate that factors such as the "passengers," "number of vehicles," "number of employees," "autonomous community deficit", and "population density" are influencing factors for the needs of public subsidies.

Finally, we believe that the implications of our work are of value to operating companies as well as regulators of public transport financing. 
This paper is structured in four parts. First, we review the literature studying the importance of sustainable public transportation and its issues in Spain. Second, we share our sample, methodology, and hypotheses. In the third section, we present the obtained results. Finally, the last section contains our conclusions.

\section{Literature Review: Public Transportation, Financial Sustainability, and Fare Deficit}

According to the Instituto Nacional de Estadística [7], the population of Spain has increased by 7 million over the last 20 years mainly in metropolitan areas. This implies that all public services, including passenger transport, must increase their service offerings while maintaining a good quality/price ratio and considering sustainable mobility policies.

Sustainable urban mobility has a strong impact on the economy in addition to its effects on social and environmental issues. Cities' competitiveness depends, to a large extent, on its citizens ability to move in the best possible way. Multiple European Union white papers on transportation policy support this view $[8,9]$. There are numerous examples of cities that disregard this lesson and wind up with congestion problems and noteworthy productivity declines. For this reason, public authorities must organize sufficient transportation networks-with or without deficit-and secure them with guaranteed and sustainable financing that usually takes the form of a percentage of public funds to complement revenue from user fees. The literature on the economic impact of public transportation is extensive and diverse. Notwithstanding, it shows some common conclusions: improvements in collective urban transportation systems contribute decisively to progress, competitiveness, and country-wide development [10]. Some UK studies have identified benefit improvements of up to $25 \%$ when improving transportation networks in specific environments [11, 12].

There is also a wide-ranging bibliography on the effect of subsidies and public transportation financing. Research on the financial sustainability of public transport focuses on different approaches such as the relationship between subsidies and the type of transportation network [13], in which the researchers pointed out the importance of encouraging investment in public transport networks rather than private ones, in order to increase social welfare; studies carried out for Mohring, 1972; Martin, 2001 [14]; Parry \& Small, 2009 about the effect of subsidies on demand encourage the granting of aid with the aim of increasing the number of passengers, offering them the appropriate resources to increase their efficiency. Other studies about the effect of subsidies in terms of social benefits and their impact on urban development [15-21] have reached conclusions that indicate how subsidies from administrations have an impact on the development of cities, since if they promote private transport, the urban area expands, with the opposite effect occurring in the case of public transport. On the other hand, starting with the seminal work of Mohring [22], academics attempt to model optimal fees and public price levels for transportation ([23-26]; among others) which draw conclusions based on the marginal cost model depending on different agents such as waiting times, travel distance, etc. and their relationship with the applied fare. Another group of researchers study the origins and implications of public support of transportation [27, 28] encouraging the granting of subsidies, after the achievement of a series of parameters such as the increase in passengers or the accomplishment of a series of efficiency indicators that reflect implications of public support of transportation. In conclusion, the literature on the effects of public support on transportation financing is diverse and international.

Within Spain, there are few studies analysing the situation of public transportation operators, their societal impact, or how public subsidy allocation can influence urban development. In the same vein, there is little research on the needs of public subsidies of public transportation operating companies or analyses of their efficiency. De Rus [29] performs a pioneering study that analyses the behavior of public urban transport costs in Spain. Its conclusions are that municipal companies have a greater number of workers and higher costs than privately run operators. Other studies similarly note that the system of public financing of transportation is inefficient and operating companies are not incentivized to minimize costs due to a lack of market competition [30, 31]. From a different perspective Ruiz Montañez [6] and Delgado Jalón et al. [32] analyse the current financing system and reveal the need for state-level regulation of transportation financing. Despite these studies, the situation has pretty much remained unchanged in three decades [33]. Therefore, it is worth asking if it is possible to achieve an efficient and financial sustainable public transportation system in the long term, while keeping current quality levels. A review of the literature has shown that there are no studies analysing the effectiveness and sustainability of Spanish public transport in the long term. Even though studies like Vassallo and Pérez de Villar [34], which indicate that in the case of intercity buses operated by private companies, regulated competition contributes to increased efficiency and reduced costs without compromising quality. This conclusion is based solely on intercity buses in the community of Madrid and therefore it is not possible to generalize its results.

Another important aspect is the complex structure of current cities. It is common to have to expand the lines of public transport to guarantee adequate mobility. Furthermore, transportation systems extend over territories that are institutionally fragmented. Their limits do not always coincide with political or administrative boundaries [35] and thus the source of public financing can be under question. In Spain, this is an essential consideration as there is an administrative structure based on three levels: state, autonomous community, and locality. While urban transport is preeminently a local issue that takes place in cities, mobility needs often surpass the initial urban nucleus and spill over into surrounding metropolitan areas.

With regard to financing methods, public transport subsidies have traditionally been financed through general taxation. In this model, authorities collect revenue from a variety of taxable sources without a specific designation. This puts the funds into competition with other essential public services such as Health or Education. Transportation 
TABLE 1: Criteria for state aid to public transport.

\begin{tabular}{lcc}
\hline A. & $5 \%$ & Municipal transportation network length (in one-way kilometers) \\
\hline B. & $5 \%$ & Demand (ratio of travelers/citizens) \\
\hline C. & $5 \%$ & Environmental criteria \\
\hline D. & $85 \%$ & Average ticket deficit \\
\hline
\end{tabular}

Source: authors' own.

often takes second place when prioritizing among these [5]. One of the financing challenges in Europe, the Americas, or Asia is to identify financing sources that specifically support transportation in order to guarantee its long-term financial sustainability.

In Europe, legislation on public transport financing has traditionally been left up to its member states. In contrast to Spain, other European countries utilize varied financing methods. In the last decades, Germany has increased the quality of its public transport service, increasing number of passengers and performance while reducing costs and need for subsidies [3]. For example, Germany and Italy provide a greater role for public aid versus fee revenue, while the opposite is true in the United Kingdom and France. Even then, both countries count with additional taxes that provide significative financing to their systems (congestion tax in London and the versement transport tax in Paris). All these countries have a stable regulatory framework that provides binding rules to the different administrative stakeholders for meeting measurable medium- and long-term goals.

In Spain, the state has historically remained vigilant and responsible for the financing of transport infrastructure networks. Specifically, public transport financing is regulated by Law 7/1985, Regulation of the Basis of Local Regimes. Its only binding obligation is that municipalities with more than 50,000 inhabitants must offer public transport service. Several Autonomous Communities contribute to the financing of public urban transport as reflected in different laws and decrees. What is lacking in all of them is a commitment to contribute to this type financing in a stable manner. This seems to contradict the fact that it is an essential and compulsory public service according to state law [36]. This erratic financing framework along with a shortfall in public subsidies after the economic crisis has put to the test the economic and financial sustainability of the country's public transport system. A recent study by ATUC [37] makes evident that the legal void in this area affects the transportation system's deficitary nature. There are great unbalances in resource assignation among cities. Large cities are especially penalized by this system, since their costs and fees are relatively fixed while their subsidies suffer substantial swings. It may be that the problem is more about inadequate distribution than lack of resources. A notable exception to this situation is the private-public partnership agreement that inserts greater rationality and balance into the financing system. In consequence, we believe that the current system's greatest weakness is its obsolete resource distribution model.

Our analysis of the theory behind different financing systems indicates that optimal distribution systems are based on formulas. In practice, Spain's surrounding countries implement models that tie up release of public funds to achieving certain objectives thereby increasing efficiency and quality.

In essence, identifying the variables that currently determine public transport service financing needs seems to be like a key step toward being able to design a system of subsidy payouts linked to quantitative goals.

\section{Research Question (or Hypothesis), Sample, Variables, and Methodology}

3.1. Research Question. During the last decade, studies to identify public support needs have gained strength. Cities' distribution and planning have changed as they are expected to be increasingly sustainable and competitive. Furthermore, civil society has become more participatory and critical of public policies.

Absent a private-public partnership agreement, the needs of public subsidies (understood as costs that are not covered by fee revenue) at operating companies are subsidized by town hall budgets. In turn, town halls receive a modest amount of aid from the state (between $10 \%$ and 20\%). This amount is determined by the following criteria (as shown in Table 1): $85 \%$ according to the average deficit per ticket, $5 \%$ following certain environmental criteria, 5\% depending on the ratio of travellers/citizens, and the last $5 \%$ based on the length of the network (measured in one-way kilometers).

Assigning $85 \%$ of the aid based on average ticket deficits can create perverse incentives. An operating company in a municipality with high demand may still have a high fare deficit if they allow their costs to run out of control. We believe it is necessary to review the current criteria.

As noted by researchers in the area, the current legislation does not encourage or reward efficiency or solutions to reduce the needs of public subsidies. While there is agreement regarding the fact that the current model must be reformulated, there do not exist empirical studies that analyse the factors that affect costs that are not covered by fee revenues in Spanish urban transport. We thus present the following question:

Q: Can the main explanatory factors for public transportation service financing needs in Spain be identified?

The goal of this research question is to identify the factors that influence public transport financing needs and their relationship to the different criteria identified in the literature $[33,37]$. In addition, we aim to identify any existing correlations between these variables and public transportation service financing needs. 
TABLE 2: Research sample.

\begin{tabular}{|c|c|c|c|c|c|}
\hline Cities by number of citizens (sample) & & & & & TOTAL \\
\hline 50,000 to 200,000 & 5 & $36 \%$ & 9 & $64 \%$ & 14 \\
\hline 200,000 to 500,000 & 6 & $43 \%$ & 8 & $57 \%$ & 14 \\
\hline 500,000 to $1,000,000$ & 3 & $75 \%$ & 1 & $25 \%$ & 4 \\
\hline Over $1,000,000$ & 2 & $100 \%$ & 0 & $0 \%$ & 2 \\
\hline TOTAL & 16 & $47 \%$ & 18 & $53 \%$ & 34 \\
\hline
\end{tabular}

Source: authors' own.

3.2. Sample. We utilize different sources to overcome the lack of homogeneous information. Economic and financial data are from the SABI database. (The Iberian Balance Sheets Analysis System (SABI) is a tool that provides balance sheet information for over 1.3 million businesses in Spain and 400,000 in Portugal.) Data on transportation services, such as number of passengers, kilometers in network, lines of service, ownership of operating company, single ticket fares, and annual statements, are obtained from the TUC Observatory, the Metropolitan Mobility Observatory and the Ministry of Finance and Public Administrations. Data related to the public transportation sector such as the existence or not of a transportation authority or legislation on its financing was obtained from the White Book of Urban Transport Financing edited by ATUC [38]. Finally, macroeconomic data at the state, autonomous community, and local levels were obtained from official entities such as the Court of Auditors (https://www.tcu.es and http://www.rendiciondecuentas.es/es/index.html) and the National Statistical Institute (https://www.ine.es).

Spanish municipalities with a population over 50,000 must offer collective urban transport as a municipal service [39]. Therefore, the research population is made of the group of public and private entities that operate in these 144 municipalities. The sample includes 34 public and private operating companies for public transport services (see Table 2). Due to the difficulty of accessing data, it has not been possible to analyse the total sample. The study is performed during the 2008-2013 timeframe. The selected sample represents $68 \%$ of the sector by number of passengers.

As shown in Table 2, the sample is made up of $53 \%$ privately owned and $47 \%$ publicly owned companies. We believe the diversity of firms and municipalities as well as the extended timeframe included in the sample provide sufficient data to analyse the research question. Some firms were excluded because of insufficient data.

3.3. Variables. Needs of public subsidies is considered as the dependent variable. Table 3 presents the independent variables as collected from the data sources. As a public service, the general economic situation has a direct influence on both the management and results of operating companies. For these reasons, we include economic variables such as unemployment rate or citizens' income levels. During the range of years on which this study is based, Spain was immersed in a pressing economic crisis, so these variables suffered significant variations. Specifically, the unemployment rate reached an all-time high, rising from $13.79 \%$ to $25.73 \%$, according to the Spanish Statistical Office (INE) (https://www.ine.es/) data. Regarding GDP per capita, it fell from $24,300 €$ to $22,518 €$, data obtained through the INE also. Both variables, since they influence the purchasing power of users, have repercussions at the time of making their journeys in their cities and, therefore, have an effect on the demand for urban transport services.

As observed in the literature review, a city's makeup is an important component for understanding mobility and transportation management. To reflect this, we include sociodemographic variables such as population extension and degree of concentration or dispersion of the municipality and alternative modes of transport, since both the potential passengers represented by the population and the size of the municipality in which the service is to be provided, together with possible competition with other modes of transport, influence the calculation of sources of funding.

We also have operational variables that depend on management decisions of the operating companies, such as their personnel, fleet size choices, vehicles, or kilometers. According to published data [40], these factors have evolved differently. With respect to the needs of the fleet, the number of buses dedicated by the companies to urban public transport has not undergone practically any variation in the range of years under study, going from 1,008 buses to 998. The variation of passengers transported had a decline over those years, affected by the economic crisis mentioned above. The global amount went from 1,810,034 passengers to $1,625,648$ passengers, representing a decrease of just over $10 \%$ during the period of study.

With regard to the kilometers covered, the decrease has been important, from 117,385 million to 62,220 million, much more relevant than in the previous variable. These data had an effect on other variables such as the number of employees of the operating companies, as well as drivers. The companies were forced to adjust their personnel policies, causing a decrease in the data for both variables.

Finally, we have incorporated variables that we consider related to mobility policy-making and that we believe may influence financing needs. Specifically, we considered pricing policy, which is a competence of the local and autonomous communities, a determinant factor for an operator's ability to generate revenue. Therefore, we include among the independent variables the ruling political party in the autonomous community or city hall. Other variables are the availability of other modes of transportation; affiliation to a transportation 
TABLE 3: Independent variables.

\begin{tabular}{|c|c|c|c|c|}
\hline Category & Acronym & Variable & Type & $\begin{array}{c}\text { Measurement } \\
\text { unit }\end{array}$ \\
\hline Mobility policy & Ownership & $\begin{array}{l}\text { Operating company } \\
\text { ownership, whether the } \\
\text { operating company is } \\
\text { public or private. }\end{array}$ & $\begin{array}{l}\text { Qualitative- } \\
\text { dichotomous }\end{array}$ & $0 / 1$ \\
\hline Economic & Unemployment & $\begin{array}{l}\text { Unemployment rate, } \\
\text { unemployment rate in the } \\
\text { autonomous community } \\
\text { where the analysed } \\
\text { company operates. }\end{array}$ & Quantitative & $(\%)$ \\
\hline Economic & GDP & $\begin{array}{l}\text { GDP per capita, GDP per } \\
\text { capita by Autonomous } \\
\text { Communities in which the } \\
\text { analysed company operates. }\end{array}$ & Quantitative & $(€ /$ citizen $)$ \\
\hline Operational & Passengers & $\begin{array}{c}\text { Passengers, number of } \\
\text { passengers. }\end{array}$ & Quantitative & (no.) \\
\hline Mobility policy & Price & Price of single ticket. & Quantitative & $(€)$ \\
\hline Operational & Vehicles & $\begin{array}{l}\text { Vehicles, vehicles per } \\
\text { company. }\end{array}$ & Quantitative & (no.) \\
\hline Operational & $\mathrm{KM} /$ tra. & Kilometers travelled. & Quantitative & (no.) \\
\hline Operational & Lines & $\begin{array}{l}\text { Lines, number of lines } \\
\text { operated by the company. }\end{array}$ & Quantitative & (no.) \\
\hline Political & COMM/par. & $\begin{array}{l}\text { Autonomous community } \\
\text { party, political party that } \\
\text { governs in the autonomous } \\
\text { community. }\end{array}$ & Qualitative & \\
\hline Mobility policy & FIN/reg. & $\begin{array}{c}\text { Local or autonomous } \\
\text { community-level financing } \\
\text { regulation. }\end{array}$ & $\begin{array}{l}\text { Qualitative- } \\
\text { dichotomous }\end{array}$ & $0 / 1$ \\
\hline Economic & COMM/def. & $\begin{array}{l}\text { Autonomous community } \\
\text { deficit, number of operating } \\
\text { expenses not covered by } \\
\text { tariff revenues per } \\
\text { Autonomous Community. }\end{array}$ & Quantitative & $(\%)$ \\
\hline Economic & MUN/def. & $\begin{array}{l}\text { Municipal deficit per } \\
\text { citizen, number of } \\
\text { operating expenses not } \\
\text { covered by tariff revenues } \\
\text { per citizen (by } \\
\text { municipalities). }\end{array}$ & Quantitative & $(€ /$ citizen $)$ \\
\hline Mobility policy & TRSP/aut. & $\begin{array}{l}\text { Transport authority } \\
\text { (organisms). }\end{array}$ & $\begin{array}{l}\text { Qualitative- } \\
\text { dichotomous }\end{array}$ & $0 / 1$ \\
\hline Sociodemographic & Metro/light rail & $\begin{array}{l}\text { Metro/light rail in the } \\
\text { municipality. }\end{array}$ & $\begin{array}{l}\text { Qualitative- } \\
\text { dichotomous }\end{array}$ & $0 / 1$ \\
\hline Operational & Employees & $\begin{array}{l}\text { Employees, number of } \\
\text { employees per company. }\end{array}$ & Quantitative & (no.) \\
\hline Operational & Drivers & $\begin{array}{c}\text { Drivers, number of drivers } \\
\text { per company. }\end{array}$ & Quantitative & (no.) \\
\hline Sociodemographic & POP/den. & $\begin{array}{l}\text { Population density, average } \\
\text { number of citizens in the } \\
\text { autonomous community } \\
\text { where the analysed } \\
\text { company operates. }\end{array}$ & Quantitative & citizens $/ \mathrm{m}^{2}$ \\
\hline
\end{tabular}

Source: authors' own. 
TABLE 4: Descriptive statistics for quantitative variables.

\begin{tabular}{|c|c|c|c|c|}
\hline & Minimum & Maximum & Average & Standard deviation \\
\hline Unemployment rate & $6.60 \%$ & $40.47 \%$ & $21.43 \%$ & $7.75 \%$ \\
\hline GDP & 15026.00 & 31791.00 & 22268.99 & 4395.07 \\
\hline Passengers & 564492.00 & 426586901.00 & 37557931.74 & 78836949.88 \\
\hline Price & 0.45 & 2.00 & 1.08 & 0.26 \\
\hline Vehicles & 11.00 & 2100.00 & 191.86 & 395.94 \\
\hline $\mathrm{KM} /$ tra. & 777232.00 & 468670549.00 & 10670222.84 & 38455547.82 \\
\hline Lines & 5.00 & 216.00 & 30.51 & 40.40 \\
\hline COMM/def. & $-.0492 \%$ & $.0078 \%$ & $-.0209168 \%$ & $.0116239 \%$ \\
\hline MUN/def. & -273.00 & 10000.00 & 1228.83 & 3212.78 \\
\hline Employees & 31.00 & 10541.00 & 785.12 & 1631.45 \\
\hline Drivers & 29.00 & 6418.00 & 560.22 & 1110.07 \\
\hline POP/den. & 100.88 & 16510.92 & 2983.69 & 3390.22 \\
\hline Needs/PS & 268718.37 & 282349282.00 & 27851404.49 & 53339433.72 \\
\hline
\end{tabular}

Source: authors' own.

authority that regulates and organizes transportation systems under its area of influence; or the existence of local or autonomous community-level regulation that reflects concern for the organization of the transportation system.

Table 3 presents the variables for which we wish to explore possible relationships with the needs of public subsidies (Needs/PS). Each variable includes a description of its type and measurement unit.

3.4. Methodology. We perform a detailed descriptive analysis of the sample in order to characterise the variables under study. Following this, we analyse the correlations of the dependent variable with each independent variable. To aid with interpretation, we segmented independent variables into two groups. In Group 1, we study the correlation between the needs of public subsidies and sociodemographic and mobility variables. In Group 2, we examine the correlation of operational and economic and financial variables with the needs of public subsidies. We then generate a residual plot to verify the normality assumption.

To test our research question, we build a multiple linear regression model that has transportation company's needs of public subsidies as a response variable and the various explanatory variables listed in Table 3. Taking into account the fact that we have different types of variables, we use linear regression (pool method) because it adapts to a wide variety of situations, using an equation to express the relationship between a variable of interest [41]. Additionally, to give the robustness to the models, random effect model regression and censored Tobit model have been employed. Regression with random effects is model of regression (panel data) that combines cross section and times-series data $[42,43]$, as is the case of our model. Tobit model (also known as censored regression model) was proposed by James Tobin [44] to describe relationship between variables when there is either left- or right-censoring in the dependent variable.

Our goal is to note the existence or nonexistence of correlation between explanatory variables and the needs of public subsidies. The interpretation of these relationships informs the search for optimal distribution criteria of public subsidies that could form the backbone of a future Spanish public transportation financing law.

\section{Results and Discussion}

4.1. Descriptive Analysis and Linear Regression. Table 4 presents a descriptive analysis of the sample. The average number of passengers is high at $37,557,931.74$ as is the standard deviation. The maximum number of vehicles is 2,100 although the average is just below 192. From these facts, we can note that this is a heterogeneous sample of operating companies. Similarly, the number of employees varies between 31 and 10,541 with an average of 785 workers. Descriptive statistics for number of drivers tell a similar story. The average is 560 but some companies have up to 6,418 drivers. Another important variable is population density (citizens $/ \mathrm{km}^{2}$ ); the minimum and maximum values range between 100 and 16,510. This is also an indicator of the diversity within the territories covered. Some networks must extend far to cover sparsely populated areas while others are much denser.

Within the economic and mobility variables, it is notable that the range of single ticket fares is between 0,45 and 2 euros with an average of 1,08 euros. It is evident that there is a wide disparity of mobility policies among municipalities with differences of over $100 \%$. The PIB per capita has a relatively low standard deviation with an average of 22,269.

The needs of public subsidies are as diverse as the rest of the sample, with large differences between maximum and minimum values and high standard deviation values. Overall, operating companies have an elevated deficit of 27,851,404 on average. This reflects the large gaps between operating expenses and revenue.

As we can see in the table of descriptive statistics, the difference between maximum and minimum values is very high. That is why we have chosen to normalize the sample on 
TABLE 5: Linear regression results (I).

\begin{tabular}{lcccccc}
\hline Source & SS & df & MS & Number of obs & $=$ & 191 \\
& & & F(17, 173) & $=$ & 411.90 \\
Model & 6.647 & 17 & .391 & Prob $>$ F & $=$ & 0.00 \\
Residual & 0.164 & 173 & .001 & R-squared & $=$ & 0.9759 \\
Total & 6.811 & \multirow{2}{*}{0.036} & Adj R-squared & $=$ & 0.9735 \\
& & & Root MSE & $=$ & 0.0308 \\
\hline
\end{tabular}

Source: authors' own.

the basis of feature scaling; specifically, linear scaling to unit range was used. This method is widely used to standardize the range of variables or feature of data [45].

The next step in our statistical analysis is to evaluate the correlation matrix between dependent and independent variables. Firstly, we analyse correlation of sociodemographic and mobility variables with the needs of public subsidies. Specifically, the correlated variables are PIB per capita, single ticket fare, governing party in the autonomous community where the firm operates, the existence of metro or light rail, the existence of a transport authority, and population density. Correlation is only beyond the commonly accepted thresholds for the metro/light rail and population density variables. Economic variables like autonomous community deficit, city hall deficit, or unemployment rate do not show correlation with the dependent variable. Secondly, we analyse the correlation levels between the response variable and explanatory variables linked to operational and additional mobility policy issues. Counterintuitively, there is weak correlation between the type of ownership (public or private) and financing needs. The rest of operational variables, except for number of passengers, do show strong correlation with the dependent variable. In addition, the mobility policy variable "local or autonomous community-level regulation" is also correlated positively with financing needs.

The summary of linear regression shows that the independent variable explains a large percentage of the total variability in financing needs of public urban transportation firms.

As shown in Table 5, the number of observations in this model is 191. The sum of squares of 6.811 explains the variability in the needs of public subsidies, while the residual sum of squares of 0.164 represents the amount of variance that is not explained by the regression model. Even taking this into account, the model explains $97.59 \%$ of the needs of public subsidies. Furthermore, the p-value at 0.00 is within the acceptable range below 0.05 . This allows us to affirm that the chosen independent variables have explanatory value for the model.

Table 6 presents the regression coefficients associated with the selected independent variables and their significance level in the model.

The variables "ownership," "unemployment rate," "GDP per capita," "price of single ticket," "kilometers travelled," "lines," "municipal deficit," "metro/light rail," and "drivers" are not deemed significant in the regression model since their $\mathrm{p}$-value is greater than 0.05 .
Therefore, financing needs are explained by operational variables: "passengers," "number of vehicles," and "number of employees". Also, economic variable like "autonomous community deficit" and one sociodemographic variable, "population density," are one of the explanatory variables to predict the need of public subsidies. Finally, the study adds to the existing literature by discovering the impact of politics and mobility policies on financing needs. "Autonomous community party in power," "local or community-level financing regulation," and "existence of a transport authority" all influence the needs of public subsidies for public transportation.

4.2. Robustness. To ensure the viability of our results, we performed several robustness checks, because a very traditional technique has been used (multiple linear regression). To test whether the results remain constant, we use linear regression for random effects, in which the behavior of companies is observed across time. Also, the Tobit model result is provided to check robustness of model. The panel data linear regression result shows the high level of significance for the analysed model (Table 7).

In the table we see that the determination coefficient within the analysed groups is almost 0.42 , that means that independent variables explain $42 \%$ of the model within the groups, while $\mathrm{r}$ square is $96.92 \%$ for the overall model. The results of Table 8 show the degree of relationship between independent and dependent variable, thus verifying the results of multiple linear regression. As in the multiple linear regression, as well as in the random effects regression, it is shown that the variables "passengers," "number of vehicles," "number of employees," "autonomous community deficit," and "population density" explain the need for funding, while variables such as "autonomous community party in power," "local or community-level financing regulation", and "existence of a transport authority" are not significant for panel data analysis. Another interesting result is that variables "kilometers travelled" and "drivers" are significant in the regression model for panel data, although they were not for the previous analysis. This could be that if we measure the data without considering the cross section and times series, the kilometers travelled and number of drivers does not change much for the model and its influence is not significant. In case of panel data analysis, where the sample is analysed by groups, it can be observed that they are significant for each company, since this methodology takes into account obtaining information over time, for each of individuals. 
TABLE 6: Linear regression results (ll).

\begin{tabular}{|c|c|c|c|c|c|c|}
\hline Needs/PS & Coef. & Std. Err & $\mathrm{t}$ & $\mathrm{P}>\mathrm{t}$ & \multicolumn{2}{|c|}{ [95\% Conf. Interval] } \\
\hline Ownership & -0.007 & 0.006 & -1.140 & 0.255 & -0.020 & 0.005 \\
\hline Unemployment rate & -0.011 & 0.014 & -0.800 & 0.425 & -0.038 & 0.016 \\
\hline GDP & -0.005 & 0.014 & -0.340 & 0.737 & -0.032 & 0.022 \\
\hline Passengers & -0.333 & 0.105 & -3.160 & 0.002 & -0.541 & -0.125 \\
\hline Price & -0.026 & 0.020 & -1.260 & 0.210 & -0.066 & 0.015 \\
\hline Vehicles & 1.004 & 0.198 & 5.080 & 0.001 & 0.614 & 1.395 \\
\hline $\mathrm{KM} /$ tra. & 0.298 & 0.177 & 1.680 & 0.094 & -0.051 & 0.647 \\
\hline Lines & -0.007 & 0.058 & -0.120 & 0.903 & -0.121 & 0.107 \\
\hline COMM/par. & 0.009 & 0.002 & 4.390 & 0.001 & 0.005 & 0.014 \\
\hline FIN/reg. & -0.022 & 0.011 & -1.940 & 0.054 & -0.044 & 0.000 \\
\hline COMM/def. & -0.502 & 0.211 & -2.380 & 0.018 & -0.918 & -0.086 \\
\hline MUN/def. & 0.006 & 0.017 & 0.360 & 0.720 & -0.027 & 0.039 \\
\hline TRSP/aut. & 0.017 & 0.007 & 2.390 & 0.018 & 0.003 & 0.031 \\
\hline Metro/light rail & 0.014 & 0.009 & 1.610 & 0.109 & -0.003 & 0.031 \\
\hline Employees & 0.337 & 0.099 & 3.420 & 0.001 & 0.142 & 0.531 \\
\hline Drivers & -0.318 & 0.197 & -1.620 & 0.107 & -0.707 & 0.070 \\
\hline POP/den. & 0.094 & 0.018 & 5.150 & 0.001 & 0.058 & 0.130 \\
\hline _cons & -0.032 & 0.010 & -3.300 & 0.001 & -0.049 & -0.013 \\
\hline
\end{tabular}

Source: authors' own.

TABLE 7: Random effects GLS regression results (I).

\begin{tabular}{|c|c|c|c|}
\hline Random-effects GLS regression & Number of obs & $=$ & 191 \\
\hline Group variable: IDcompany & Number of groups & $=$ & 34 \\
\hline R-sq: & Obs per group: & & \\
\hline within $=0.419$ & $\min$ & $=$ & 3 \\
\hline between $=0.969$ & avg & $=$ & 5.6 \\
\hline overall $=0.967$ & $\max$ & $=$ & 6 \\
\hline \multirow{2}{*}{$\operatorname{corr}\left(\mathrm{u} \_\mathrm{i}, \mathrm{X}\right)=0$ (assumed) } & Wald chi2(17) & $=$ & 1561.64 \\
\hline & Prob > chi 2 & $=$ & 0.00 \\
\hline
\end{tabular}

Source: authors' own.

Due to differences in the results we have applied, the Tobit model is an additional robustness model. Tobit model is used to estimate linear relationships between dependent variable and independent variables, when the values of dependent variables are censoring to below or above. In our case, there are 17 left-censored observations $<=0,174$ uncensored observations, and 0 right-censored observations. The model's probability of chi2 is 0.00 , so we proceed to analyse the results of this model, along with the coefficients of two other regressions previously analysed. A comparison of the results of the three models is shown in Table 9.

As can be observed in the table we have matched the results of these three models. There are some independent variables that in all three models have been significant, such as "passengers," "number of vehicles," "number of employees," "autonomous community deficit," and "population density". Therefore, these five variables can be considered important when we explain the need for public transport funding. Although, if we look at the coefficients obtained from the variable "passengers," we observe that in case of analysis of panel data the result is positive, which means that if the number of passengers increases, the need for funding is increased too. While in two other analyses it is observed that if the number of passengers decreases, the need for financing increases. This result should explain that, in smaller cities, service offer is more deficient since demand does not cover an offer that cannot be reduced much either because there is a basic minimum network of services (there is excess of capacity). In this case, an increase in the number of passengers means a reduction in costs and therefore a reduction in the needs of public subsidies. In larger cities, where there is greater dependence on public transport, supply and demand are consistent. In these cases, an increase in passengers can lead to an increase in installed capacity costs (more buses, frequencies, etc.), which lead to greater needs of public subsidies. In the panel data analysis, data are usually collected over time and over the same individuals and then a regression is run over these two dimensions; therefore, it could be that larger cities have set the trend in this analysis, which did not happen in the pool and Tobit 
TABLE 8: Random effects GLS regression results (1l).

\begin{tabular}{|c|c|c|c|c|c|c|}
\hline Needs/PS & Coef. & Std. Err & $\mathrm{z}$ & $\mathrm{P}>\mathrm{Z}$ & \multicolumn{2}{|c|}{ [95\% Conf. Interval] } \\
\hline Ownership & -0.012 & 0.012 & -1.000 & 0.316 & -0.035 & 0.011 \\
\hline Unemployment rate & -0.005 & 0.011 & -0.480 & 0.633 & -0.027 & 0.016 \\
\hline GDP & -0.013 & 0.022 & -0.570 & 0.568 & -0.056 & 0.031 \\
\hline Passengers & 0.225 & 0.074 & 3.050 & 0.002 & 0.080 & 0.369 \\
\hline Price & -0.023 & 0.016 & -1.450 & 0.146 & -0.055 & 0.008 \\
\hline Vehicles & 0.910 & 0.155 & 5.870 & 0.001 & 0.606 & 1.213 \\
\hline $\mathrm{KM} /$ tra. & 0.437 & 0.139 & 3.140 & 0.002 & 0.164 & 0.711 \\
\hline Lines & 0.054 & 0.061 & 0.880 & 0.379 & -0.066 & 0.173 \\
\hline COMM/par. & 0.002 & 0.002 & 1.000 & 0.315 & -0.001 & 0.005 \\
\hline FIN/reg. & 0.017 & 0.016 & 1.040 & 0.297 & -0.015 & 0.048 \\
\hline COMM/def. & -0.222 & 0.117 & -1.890 & 0.058 & -0.451 & 0.008 \\
\hline MUN/def. & 0.013 & 0.010 & 1.350 & 0.176 & -0.006 & 0.032 \\
\hline TRSP/aut. & 0.003 & 0.013 & 0.220 & 0.823 & -0.023 & 0.029 \\
\hline Metro/light rail & 0.031 & 0.017 & 1.810 & 0.070 & -0.003 & 0.065 \\
\hline Employees & 0.172 & 0.056 & 3.080 & 0.002 & 0.063 & 0.281 \\
\hline Drivers & -0.912 & 0.124 & -7.380 & 0.001 & -1.154 & -0.669 \\
\hline POP/den. & 0.131 & 0.028 & 4.640 & 0.001 & 0.076 & 0.186 \\
\hline _cons & -0.021 & 0.012 & -1.800 & 0.071 & -0.045 & 0.002 \\
\hline sigma_u & 0.024 & & & & & \\
\hline sigma_e & 0.014 & & & & & \\
\hline rho & 0.757 & & (fraction & due to $\mathrm{u} \_\mathrm{i}$ ) & & \\
\hline
\end{tabular}

Source: authors' own.

TABLE 9: Comparison of the results.

\begin{tabular}{lccc}
\hline Needs/PS & Coef. (Pool) & Coef. (Random) & Coef. (Tobit) \\
\hline Ownership & -0.007 & -0.012 & -0.003 \\
\hline Unemployment rate & -0.011 & -0.005 & -0.015 \\
\hline GDP & -0.005 & -0.013 & -0.011 \\
\hline Passengers & $-0.333 * * *$ & $0.225 * * *$ & $-0.294 * *$ \\
\hline Price & -0.026 & -0.023 & -0.016 \\
\hline Vehicles & $1.004 * * *$ & $0.910 * * *$ & $0.901 * * *$ \\
\hline KM/tra. & $0.298 *$ & $0.437 * * *$ & $0.358 * *$ \\
\hline Lines & -0.007 & 0.054 & 0.000 \\
\hline COMM/par. & $0.009 * * *$ & 0.002 & $0.009 * * *$ \\
\hline FIN/reg. & $-0.022 *$ & 0.017 & $-0.021 *$ \\
\hline COMM/def. & $-0.502 * *$ & $-0.222 * *$ & $-0.531 * *$ \\
\hline MUN/def. & 0.006 & 0.013 & 0.002 \\
\hline TRSP/aut. & $0.017 *$ & 0.003 & 0.012 \\
\hline Metro/light rail & 0.014 & $0.031 *$ & $0.018 * *$ \\
\hline Employees & $0.337 * * *$ & $0.172 * * *$ & $-0.331 * * *$ \\
\hline Drivers & -0.318 & $-0.912 * * *$ & -0.313 \\
\hline POP/den. & $0.094 * * *$ & $0.131 * * *$ & -0.021 \\
\hline cons & -0.032 & -0.037 \\
\hline
\end{tabular}


analysis. The variable "kilometers travelled" is significant in both of robustness tests, even though its correlation with financial needs is very weak in the main analysis, while the variable "autonomous community party in power" explains the need for funding in the regression and Tobit models, but not through panel data analysis.

\section{Conclusions}

Interest in increasing efficiencies in the Spanish public transportation industry has grown over the last few decades $[29,31]$. Our review of current research shows that the lack of a national regulatory framework for public transportation has downstream effects on the distribution of public subsidies, which then impacts cities' ability to provide sustainable mobility. The goal of this study is to identify the factors that influence the needs of public subsidies for public transportation operating companies. This is achieved by examining a sample of Spanish public transport operators. The resulting variables might form the basis of a future system to determine public transport subsidy distribution.

The Spanish public transportation system is not hindered as much by a lack of resources than by their inadequate distribution. Autonomous communities only have a direct involvement in cities that have metro, light rail, and/or light metro, with this last category being highly subsidized. City halls are the main entities responsible for the maintenance of urban bus networks after the state has progressively stepped away and focused its attention on the train system. Privatepublic partnership agreement is an exception that allows for a more organized and balanced financing system. It appears that the greatest weakness of the current system is its obsolete method for resource allocation.

Among neighboring countries, the use of formulas to determine aid distribution seems to favor arrangements that link public funds to certain goals and to efficiency and quality increases. In all cases, there are stable regulatory frameworks that bind the different administrative entities to mid- and long-term commitments as long as certain measurable goals are met. In consequence, we conclude that contractual and formula-oriented methods linked to outputs are the most effective. Both models are similar to the difference that formulas are applied retrospectively while private-public partnership agreement looks into the future in order to assign resources, which make them conceptually a better option.

Our analysis identifies the main parameters to consider in a new model for allocating public support in Spanish public urban transportation operating companies. Based on our research, we believe that the formula should contain not only the more evident operational and sociodemographic variables that identify the level of service needed but also economic variables. Taking into account all these variables it could be possible to improve the efficiency of the transportation system and result in a decreased need for public financing.

Contrary to what is traditionally believed, one of the most noteworthy conclusions of this study is that the type of management, public or private, of transport companies does not seem to have a significant influence on the financing needs of these companies. From a sociodemographic perspective, the most influential factor on financing needs is population density, not being significant coexistence with alternative means of mass transportation (metro or light rail).

Regarding the operational variables, results were-as seems logical-most strongly related to the number of vehicles, kilometers travelled, number of workers, or number of drivers. Of the economic variables studied, the autonomous community deficit is the only one with significant influence for the needs of public subsidies. After the different robustness analyses were carried out, the variables related to mobility policies have not proved to be influential.

The model we generated has an explanatory power of $97.59 \%$. Globally, the most significant variables are passengers, number of employees, vehicles, kilometers, population density, and autonomous community deficit.

\section{Data Availability}

The variables used in the study come from different sources. The readers can access the data through the following webpages: https://www.ine.es/, Spanish Statistical Office; http://www.rendiciondecuentas.es/es/index.html, Accountability Portal; https://www.atuc.es/observatorio-movilidadmetropolitana-publica-ultimo-informe, the reports published in the Metropolitan Mobility Observatory; https://www.madrid.es/portal/site/munimadrid, websites of the cities where the analysed companies operate (i.e., Madrid); https://sabi.bvdinfo.com/homeversion-2019121/ .serv?product=SabiNeo, the economic-financial data have been obtained through the SABI database; http://www interior.gob.es/, Ministry of Interior; White Book on financing urban transport, association of Urban Collective Transport Management Companies ATUC- [38].

\section{Conflicts of Interest}

The authors declare that they have no conflicts of interest.

\section{Acknowledgments}

This research work has taken place within the research project "Alternatives for Urban Transportation Financing" (Ref. V589) financed by the Association of Urban Collective Transport Management Companies (ATUC).

\section{References}

[1] M. A. Sánchez de Lara, Estudio predictivo de costes y financiación del servicio de transporte urbano colectivo en las empresas españolas mediante la aplicación de redes neuronales artificiales dissertation [Doctoral thesis], Universidad Rey Juan Carlos, 2013.

[2] D. Banister, Unsustainable Transport: City Transport in the New Century Routledge, London, UK, NY, USA, 2005.

[3] R. Buehler and J. Pucher, "Making public transport financially sustainable," Transport Policy, vol. 18, no. 1, pp. 126-138, 2011.

[4] TRB, "Making transit work," in Insight from Western Europe, Canada and the United States, Transportation Research Board. 
National Research Council. National Academy Press, Washington, DC, USA, 2001.

[5] B. Ubbels and P. Nijkamp, "Unconventional funding of urban public transport," Transportation Research Part D: Transport and Environment, vol. 7, no. 5, pp. 317-329, 2002.

[6] M. Ruiz Montañez, "La financiación del transporte urbano: un reto para las ciudades españolas del siglo XXI," in Investigaciones Europeas de Dirección y Economía de la Empresa, vol. 20, pp. 1-4, 2014.

[7] "INE - Instituto Nacional de Estadística," http://www.ine.es.

[8] COM - Comisión Europea, "Libro Blanco de la Comisión Europea "La política europea de transportes de cara al 2010: la hora de la verdad"," COM (2001) 370 Final, de 12 de septiembre de 2001, 2001.

[9] COM - Comisión Europea, "Libro Blanco de la Comision Europea "Hoja de ruta Hacia un espacio unico europeo de transporte: por una politica de transportes competitiva y sostenible"," COM (2011) 144 Final, de 28 de marzo de 2011, 2011.

[10] D. G. Chatman and R. B. Noland, "Do Public Transport Improvements Increase Agglomeration Economies? A Review of Literature and an Agenda for Research," Transport Reviews, vol. 31, no. 6, pp. 725-742, 2011.

[11] D. J. Graham, "Agglomeration, productivity and transport investment," Journal of Transport Economics and Policy, vol. 41, no. 3, pp. 317-343, 2007.

[12] R. Vickerman, "Provision of public transport under conflicting regulatory regimes," Transportation Research Part A: Policy and Practice, vol. 42, no. 9, pp. 1176-1182, 2008.

[13] S. Tscharaktschiew and G. Hirte, "Should subsidies to urban passenger transport be increased? A spatial CGE analysis for a German metropolitan area," Transportation Research Part A: Policy and Practice, vol. 46, no. 2, pp. 285-309, 2011.

[14] R. W. Martin, "Spatial mismatch and costly suburban commuters: can commuting subsidies help?" Urban Studies, vol. 38, no. 8, pp. 1305-1318, 2001.

[15] W. Vickrey, "Optimal transit subsidy policy," Transportation, vol. 9, no. 4, pp. 389-409, 1980.

[16] Y. Zenou, "Urban unemployment, agglomeration and transportation policies," Journal of Public Economics, vol. 77, no. 1, pp. 97-133, 2000.

[17] K. Van Dender, "Transport taxes with multiple trip purposes," The Scandinavian Journal of Economics, vol. 105, no. 2, pp. 295310, 2003.

[18] J. K. Brueckner, "Transport subsidies, system choice, and urban sprawl," Regional Science \& Urban Economics, vol. 35, no. 6, pp. 715-733, 2005.

[19] R. Borck and M. Wrede, "Political economy of commuting subsidies," Journal of Urban Economics, vol. 57, no. 3, pp. 478499, 2005.

[20] R. Borck and M. Wrede, "Subsidies for intracity and intercity commuting," Journal of Urban Economics, vol. 66, no. 1, pp. 2532, 2009.

[21] Q. Su and J. S. De Salvo, "The effect of transportation subsidies on urban sprawl," Journal of Regional Science, vol. 48, no. 3, pp. 567-594, 2008.

[22] H. Mohring, "Optimization and scale economies in urban bus transportation," American Economic Review, vol. 62, no. 4, pp. 591-604, 1972.

[23] B. De Borger and S. Wouters, "Transport externalities and optimal pricing and supply decisions in urban transportation:
A simulation analysis for Belgium," Regional Science \& Urban Economics, vol. 28, no. 2, pp. 163-197, 1998.

[24] S. Proost and K. V. Dender, "Optimal urban transport pricing in the presence of congestion, economies of density and costly public funds," Transportation Research Part A: Policy and Practice, vol. 42, no. 9, pp. 1220-1230, 2008.

[25] M. Kilani, S. Proost, and S. van der Loo, "Road pricing and public transport pricing reform in Paris: Complements or substitutes?" Economics of Transportation, vol. 3, no. 2, pp. 175187, 2014.

[26] I. Kaddoura, B. KickhöFer, A. Neumann, and A. Tirachini, "Optimal public transport pricing : Towards an agent-based marginal social cost approach," Journal of Transport Economics and Policy, vol. 49, pp. 200-218, 2015.

[27] M. W. Frankena, "The efficiency of public transport objectives and subsidy formulas," Journal of Transport Economics \& Policy, vol. 17, no. 1, pp. 67-76, 1983.

[28] I. W. H. Parry and K. A. Small, "Should urban transit subsidies be reduced?” American Economic Review, vol. 92, pp. 1276-1289, 2009.

[29] G. De Rus, "El transporte público urbano en España: comportamiento de los costes y regulación de la industria," in Investigaciones Económicas (Segunda época), vol. 13, pp. 207$225,1989$.

[30] G. De Rus, "Análisis del Mercado de servicios de transporte público en España: costes, demanda, precios y nivel de calidad," Investigaciones económicas (segunda época), vol. 15, no. 2, pp. 229-247, 1991.

[31] F. López and G. De Rus, "Privatización y competencia en el transporte publico urbano de viajeros," Economistas, vol. 13, no. 63, pp. 92-101, 1995.

[32] M. L. Delgado Jalón, de. Sánchez Lara, M. A, and A. Gómez Ortega, "Financiación del Servicio Público de Transporte Urbano: Un estudio empírico en las empresas españolas," Investigaciones Europeas de Dirección y Economía de la Empresa (IEDEE), vol. 20, no. 3, pp. 151-162, 2014.

[33] Asociación de empresas gestoras de los transportes urbanos colectivos -ATUC, "Análisis de la Financiación del Transporte Público Urbano," $2^{a}$ parte, Documento de trabajo, 2017.

[34] J. M. Vassallo and P. Perez de Villar, “¿Es equitativa la política de financiación del transporte público en la Comunidad de Madrid?” VIII Congreso de Ingeniería de los Transportes (CIT2008). 02/07/2008-04/07/2008, A Coruña, 2008.

[35] R. Giménez i Capdevila, "Organización de los transportes e institucionalización de las áreas metropolitanas en Europa occidental. II Seminario Internacional de la Red de Investigación sobre Áreas Metropolitanas de Europa y América Latina (Rideal). Documento de Trabajo , núm.16," Instituto d'Estudis Territorials. Universitat Pompeu Fabra, 2004.

[36] M. A. Sánchez de Lara, M. L. D. Jalón, and J. A. R. Menéndez, "Movilidad y financiación del transporte en tiempos de crisis," in In Creando clientes en mercados globales: Building client relationships in global markets, Escuela Superior de Gestión Comercial y Marketing, ESIC, 2010.

[37] Asociación de empresas gestoras de los transportes urbanos colectivos -ATUC, "Análisis de la Financiación del Transporte Público Urbano," $1^{a}$ parte, documento de trabajo, 2016.

[38] Asociacion de empresas gestoras de los transportes urbanos colectivos -ATUC, "Libro blanco de la financiación del transporte urbano," Madrid: ATUC 2012, 2012.

[39] "Ley 7/1985, de 2 de abril, Reguladora de las Bases del Régimen Local. Boletín Oficial del Estado”. 
[40] Ministry of Public Works, "Dirección General de Transporte Terrestre," in Observatorio del transporte de viajeros por carretera, Enero, Ed., Ministerio de Fomento, 2018, NIPO: 161-15010-5.

[41] G. A. Seber and A. J. Lee, LineaR Regression Analysis, vol. 329, John Wiley \& Sons, New Jersey, USA, 2012.

[42] B. Baltagi, Econometric analysis of panel data, John Wiley \& Sons, 2008.

[43] C. Hsiao, Analysis of panel data, Cambridge University Press, 2014.

[44] J. Tobin, "Estimation of relationships for limited dependent variables," Econometrica, vol. 26, pp. 24-36, 1958.

[45] S. Aksoy and R. M. Haralick, "Feature normalization and likelihood-based similarity measures for image retrieval," Pattern Recognition Letters, vol. 22, no. 5, pp. 563-582, 2001. 


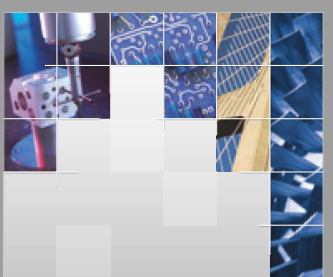

\section{Enfincering}
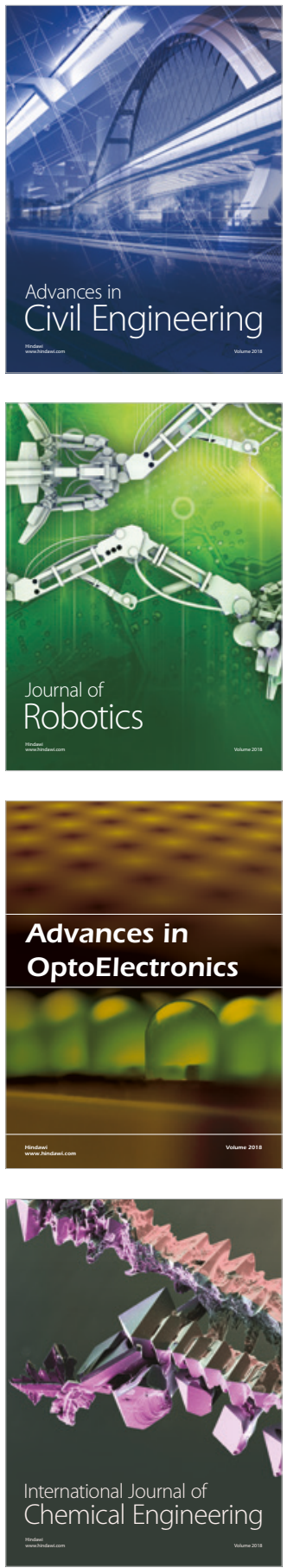

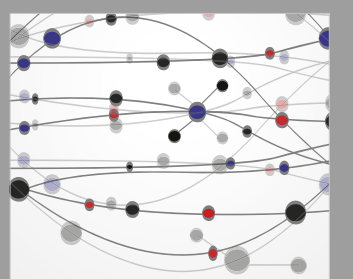

\section{Rotating \\ Machinery}

The Scientific World Journal

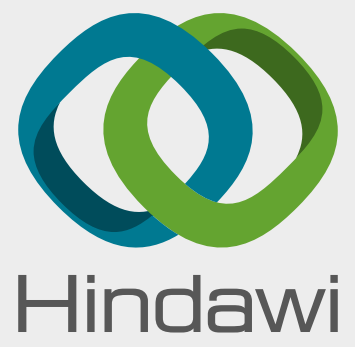

Submit your manuscripts at

www.hindawi.com
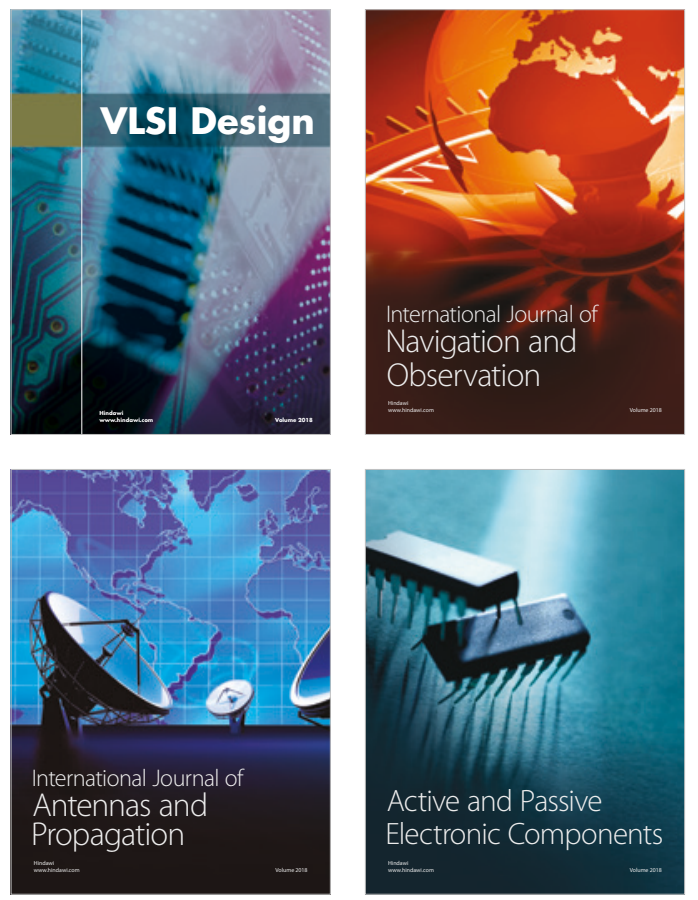
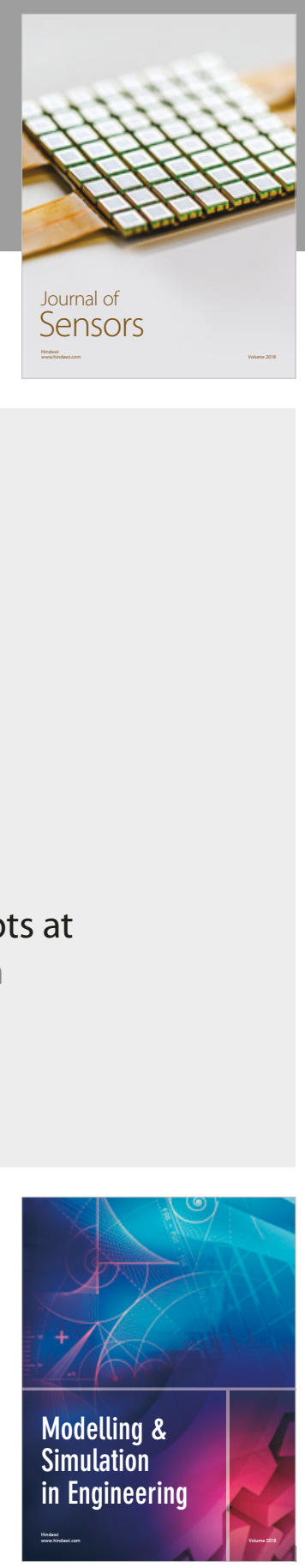

\section{Advances \\ Multimedia}
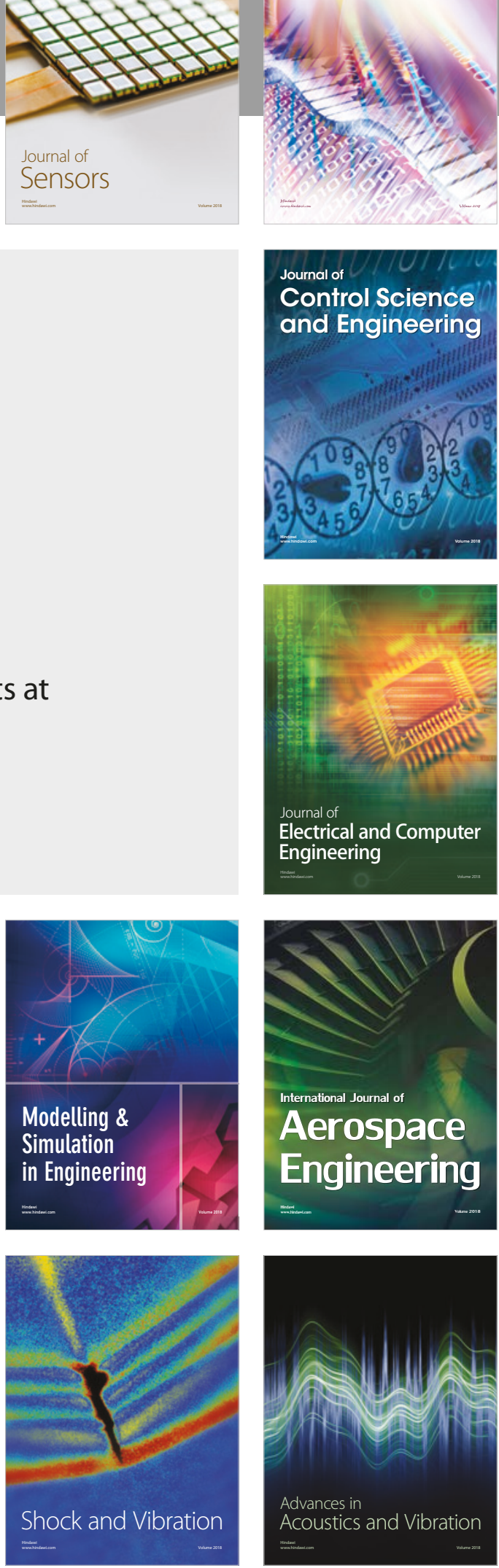